\title{
UNC13D wt Allele
}

National Cancer Institute

\section{Source}

National Cancer Institute. UNC13D wt Allele. NCI Thesaurus. Code C114614.

Human UNC13D wild-type allele is located in the vicinity of 17q25.1 and is approximately $17 \mathrm{~kb}$ in length. This allele, which encodes protein unc-13 homolog $\mathrm{D}$ protein, plays a role in the regulation of cytolytic granule secretion. Mutations in this gene are associated with familial hemophagocytic lymphohistiocytosis type 3. 